\title{
Pengaruh Pengetahuan Perpajakan, Sosialisasi Perpajakan, dan Penerapan Layanan SAMSAT Keliling pada Kepatuhan Wajib Pajak
}

\author{
Ni Putu Mita Ardiyanti ${ }^{1}$ \\ Fakultas Ekonomi dan Bisnis \\ Universitas Udayana, Indonesia
}

\author{
Ni Luh Supadmi² \\ Fakultas Ekonomi dan Bisnis \\ Universitas Udayana, Indonesia
}

\begin{abstract}
Surel : mitaardiyanti97@gmail.com
ABSTRAK

Penelitian bertujuan untuk meneliti faktor-faktor yang dapat mempengaruhi kepatuhan wajib pajak dengan berpedoman pada teori Atribusi. Faktor tersebut adalah pengetahuan perpajakan, sosialisasi perpajakan dan penerapan layanan SAMSAT keliling. Kantor Bersama SAMSAT Kabupaten Bangli dipilih sebagai tempat penelitian. Jumlah responden yang diambil sebanyak 100 orang wajib pajak dengan metode accidental sampling. Pengumpulan data dilakukan dengan menyebarkan kuesioner, lalu dianalisis dengan uji regresi linear berganda. Hasil analisis menunjukkann bahwa pengetahuan perpajakan, sosialisasi perpajakan, dan penerapan layanan SAMSAT keliling berpengaruh positif pada kepatuhan wajib pajak. Hasil penelitian ini memberikan informasi kepada Badan Pendapatan Daerah Provinsi Bali tentang pentingnya memberikan sosialisasi secara berkala, serta menambah lokasi dan jadwal layanan SAMSAT keliling sehingga dapat meningkatkan kepatuhan waijb pajak.
\end{abstract}

Kata Kunci: Pengetahuan Perpajakan; Sosialisasi Perpajakan; SAMSAT Keliling; Kepatuhan Wajib Pajak.

\section{The Influence of Tax Knowledge, Tax Socialization, and Application of Mobile Samsat Services to Taxpayer Compliance}

\section{ABSTRACT}

The research aims to examine the factors that can affect taxpayer compliance by referring to the Attribution theory. These factors are taxation knowledge, taxation socialization and mobile SAMSAT services. The SAMSAT Office in Bangli Regency was chosen as a place of research. The number of respondents taken was 100 taxpayers using the accidental sampling method. Data collection using a questionnaire, then analyzed by multiple linear regression test. The analysis shows that tax knowledge, tax socialization, and mobile SAMSAT services have a positive effect on taxpayer compliance. Regional Revenue Agency of Bali Province should provide periodic outreach, as well as increase the location and schedule of mobile SAMSAT services to increase taxpayer compliance.

Keywords: Taxation Knowledge; Tax Socialization; SAMSAT Mobile; Taxpayer Compliance.

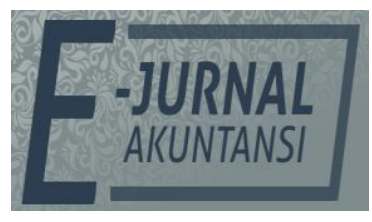

e-ISSN 2302-8556

Vol. 30 No. 8

Denpasar, Agustus 2020 Hal. 1915-1926

DOI:

10.24843/EJA.2020.v30.i08.p02

PENGUTIPAN:

Ardiyanti, N. P. M. \& Supadmi, N. L. (2020).

Pengaruh Pengetahuan

Perpajakan, Sosialisasi

Perpajakan, dan Penerapan Layanan SAMSAT Keliling pada Kepatuhan Wajib Pajak.

E-Jurnal Akuntansi, 30(8), 1915- 1926

RIWAYAT ARTIKEL: Artikel Masuk: 21 Januari 2020 Artikel Diterima: 14 Juli 2020

Artikel dapat diakses : https://ojs.unud.ac.id/index.php/Akuntansi/index 


\section{PENDAHULUAN}

Otonomi daerah memberikan kewenangan yang lebih besar bagi daerah untuk mengatur dan mengurus rumah tangganya sendiri. Pengembangan otonomi daerah dimaksudkan untuk meningkatkan kemandirian daerah yang diwujudkan salah satunya dengan memperhatikan potensi untuk mengurangi ketergantungan fiskal pada pemerintah pusat (Mahaputri \& Noviari, 2016). Kemandirian daerah berkaitan dengan kemampuan daerah dalam memenuhi kebutuhan pembiayaan pemerintahan, dan pembangunan melalui Pendapatan Asli Daerah (PAD). Pajak daerah dan retribusi daerah adalah sumber pendapatan asli daerah yang relevan guna membiayai pemerintahan dan pembangunan daerah dalam mewujudkan otonomi daerah yang nyata, dinamis, harmonis dan bertanggungjawab (Nahumury et al., 2018) .

Pajak daerah masih menjadi subkomponen terbesar dalam pencapaian realisasi Pendapatan Asli Daerah (PAD). Laporan perekonomian Provinsi Bali yang diterbitkan oleh Bank Indonesia tahun 2019 menyatakan bahwa persentase pajak daerah dalam pencapaian realisasi Pendapatan Asli Daerah pada triwulan I tahun 2019 persentase pajak daerah dalam pencapaian realisasi Pendapatan Asli Daerah mencapai 91,40 persen. Realisasi penerimaan pajak daerah didominasi oleh Pajak Kendaraan Bermotor dan Bea Balik Nama Kendaraan Bermotor. Kondisi ini sejalan dengan karakteristik Provinsi Bali sebagai destinasi pariwisata yang mengakibatkan tingginya kebutuhan akan kendaraan bermotor sebagai sarana transportasi.

Pajak Kendaraan Bermotor yang selanjutnya disebut PKB adalah pajak atas kepemilikan dan/atau penguasaan kendaraan bermotor. Pajak Kendaraan Bermotor dibebankan kepada orang pribadi atau badan yang memiliki dan/atau menguasai kendaraan bermotor. Peran Pajak Kendaraan Bermotor sebagai bagian dari pajak daerah yang begitu penting bagi Pendapatan Asli Daerah, membuat pemerintah terus berupaya memaksimalkan penerimaan pajak tersebut. Peningkatan penerimaan pajak kendaraan bermotor menjadi penting sejalan dengan bertambahnya jumlah wajib pajak kendaraan bermotor (Danarsi et al., 2017).

Penerimaan pajak harusnya dapat dimaksimalkan dengan meningkatkan kepatuhan wajib pajak, mengingat pajak merupakan salah satu sumber pendapatan yang penting (Sukmawati, 2011). Kepatuhan wajib pajak merupakan suatu kondisi wajib pajak memenuhi kewajiban, dan melaksanakan hak perpajakan dengan baik dan benar sesuai dengan peraturan perpajakan yang berlaku (Danarsi et al., 2017). Wajib pajak yang patuh cenderung melaksanakan kewajiban perpajakannya secara sukarela, sehingga memudahkan pemerintah dalam melaksanakan pungutan pajak, dan pada akhirnya meningkatkan penerimaan pajak. Ketidakpatuhan wajib pajak dapat memicu keinginan untuk melakukan penghindaran, pengelakan dan pelalaian pajak, sehingga pada akhirnya akan menghambat pembangunan suatu daerah.

Permasalahan mengenai kepatuhan wajib pajak perlu mendapat perhatian serius dari pemerintah Provinsi Bali. Data yang diperoleh dari Badan Pendapatan Daerah Provinsi Bali menunjukkan adanya peningkatan jumlah wajib pajak terdaftar seiring meningkatnya pembelian kendaraan bermotor di masing-masing kabupaten/kota. Peningkatan kendaraan terdaftar sayangnya 
belum diimbangi dengan kesediaan wajib pajak untuk patuh membayar pajak. Tahun 2014 total kendaraan terdaftar mencapai 3.268.111 unit, sementara total kendaraan yang telah membayar pajak hanya sebanyak 2.209.897 unit, artinya tingkat kepatuhan pajak pada tahun 2014 sebesar 67,62 persen. Tahun 2015 tingkat kepatuhan wajib pajak menurun sebesar 3,32 persen menjadi 64,30 persen. Tahun 2016 persentase kepatuhan wajib pajak sebesar 60,35 persen atau 3,39 persen lebih rendah dari tahun sebelumnya. Penurunan berlanjut di tahun 2017 dan 2018 dengan persentase kepatuhan wajib pajak sebesar 58,26 persen pada tahun 2017, dan sebesar 57,29 persen pada tahun 2018. Persentase tingkat kepatuhan wajib pajak yang semakin menurun mengindikasikan bahwa kepatuhan wajib pajak di Provinsi Bali tergolong rendah.

Rata-rata persentase tingkat kepatuhan wajib pajak pada masing-masing Kantor Bersama SAMSAT menunjukkan bahwa tingkat kepatuhan wajib pajak di Kabupaten Bangli dalam lima tahun terakhir rata-rata hanya mencapai 57,68 persen, artinya ada 42,32 persen dari total kendaraan terdaftar yang menunggak setiap tahunnya. Angka tersebut juga bermakna bahwa Kabupaten Bangli memiliki persentase tingkat kepatuhan wajib pajak paling rendah dibandingkan dengan kabupaten yang lain, oleh karena itu Kabupaten Bangli dipilih sebagai tempat penelitian. Perlu dilakukan kajian lebih lanjut terkait faktor-faktor yang memengaruhi kepatuhan wajib pajak.

Kepatuhan wajib pajak dalam melaksanakan kewajiban perpajakannya didasari dengan adanya pengetahuan perpajakan yang baik. Sangat penting bagi seorang wajib pajak untuk memahami hukum, undang-undang, serta tata cara yang benar dalam melaksankan kewajiban perpajakannya sebagai suatu dasar pemahaman akan perpajakan (Wardani \& Rumiyatun, 2017). Pengetahuan perpajakan yang baik akan menumbuhkan kesadaran untuk membayar pajak, sehingga wajib pajak menjadi lebih patuh (Nurhayati et al., 2015). Sebaliknya, kurangnya pengetahuan akan perpajakan berakibat pada rendahnya kesadaran wajib pajak untuk membayar pajak, karena beranggapan tidak ada insentif atau timbal balik secara langsung atas pembayaran pajak yang dilakukan (Ilhamsyah et al., 2016).

Mahaputri \& Noviari (2016) menemukan bahwa pengetahuan perpajakan secara positif memengaruhi kepatuhan wajib pajak. Hasil penelitian tersebut menunjukkan bahwa semakin baik pengetahuan perpajakan yang dimiliki, semakin tinggi tingkat kepatuhan wajib pajak. Penelitian Ummah (2015), serta Wardani \& Rumiyatun (2017) menemukan hasil yang berbeda bahwa pengetahuan perpajakan tidak memengaruhi kepatuhan wajib pajak.

Peran edukasi sangat penting dalam upaya meningkatkan kepatuhan wajib pajak sekaligus menghindarkan dari adanya informasi asimetris (Mukhlis et al., 2015). Kegiatan edukasi perpajakan salah satunya dapat diberikan dalam bentuk sosialisasi. Sosialisasi perpajakan dinilai mampu menumbuhkan kesadaran untuk membayar pajak melalui pemberian informasi dan pemahaman mengenai kebijakan perpajakan, serta tata cara perpajakan yang harus diikuti (Gustiari \& Suprasto, 2018).

Sosialisasi yang tidak optimal berakibat pada rendahnya informasi yang diterima masyarakat. Informasi yang terbatas menjadikan kurangnya pemahaman tentang kewajiban perpajakan dan cara memenuhinya, sehingga 
wajib pajak enggan untuk patuh. Wijayanti \& Sukartha (2018) dalam penelitiannya menyatakan bahwa sosialisasi perpajakan memengaruhi perilaku patuh wajib pajak secara signifikan. Hasil yang berbeda ditunjukkan dalam penelitian Savitri \& Musfialdy (2016), serta penelitian (Lianty et al., 2017) yang menyatakan bahwa tidak ada pengaruh sosialisasi perpajakan pada patuh tidaknya wajib pajak dalam menjalankan kewajibannya.

Reformasi undang-undang dan sistem administrasi perpajakan adalah salah satu upaya pemerintah untuk memperluas basis pajak dan memaksimalkan pungutan pajak dengan menjunjung asas keadilan sosial dan memberikan pelayanan prima kepada wajib pajak (Awaluddin \& Tamburaka, 2017). Pemerintah dalam hal ini Badan Pendapatan Daerah (BAPENDA) Provinsi Bali menyelenggarakan layanan unggulan SAMSAT Keliling yang mulai beroperasi pada Februari 2015 . SAMSAT Keliling adalah layanan pengesahan Surat Tanda Nomor Kendaraan (STNK), pembayaran Pajak Kendaraan Bermotor (PKB), dan Sumbangan wajib Dana Kecelakaan Lalu Lintas Jalan (SWDKLLJ) dengan menggunakan kendaraan bermotor yang beroperasi dari satu tempat ke tempat lain.

Penerapan layanan SAMSAT Keliling diduga dapat memberi pengaruh pada perilaku masyarakat khususnya wajib pajak dalam menjalankan kewajibannya. Penelitian Dwipayana et al., (2017) menunjukkan bahwa layanan SAMSAT Keliling berpengaruh positif pada kepatuhan wajib pajak. Semakin baik layanan SAMSAT Keliling yang diberikan, semakin tinggi niat wajib pajak untuk melaksanakan kewajiban perpajakannya, sehingga kepatuhan wajib pajak akan meningkat. Sebaliknya, pelayanan yang buruk akan semakin menurunkan niat masyarakat untuk memenuhi kewajiban perpajakannya, sehingga berakibat pada menurunnya kepatuhan wajib pajak.

Penelitian ini mengkaji mengenai tiga pokok permasalahan, yaitu : 1) Apakah pengetahuan perpajakan berpengaruh pada kepatuhan wajib pajak? 2) Apakah sosialisasi perpajakan berpengaruh pada kepatuhan wajib pajak? 3) Apakah penerapan layanan SAMSAT Keliling berpengaruh pada kepatuhan wajib pajak?

Teori Atribusi mengacu pada bagaimana seseorang menjelaskan penyebab dari perilaku diri sendiri atau orang lain (Nurlis \& Kamil, 2015). Teori ini mengibaratkan peneliti sebagai pengamat amatir yang berusaha memahami peristiwa atau perilaku yang terjadi disekitarnya dan menemukan penyebab hal tersebut bisa terjadi (Andreas \& Savitri, 2015). Teori Atribusi meyakini bahwa suatu peristiwa atau perilaku dapat terjadi karena adanya kombinasi antara faktor internal dan eksternal (Rahmawati \& Yulianto, 2018). Faktor internal biasanya disebabkan oleh kerpibadian alami atau elemen-elemen psikologis. Faktor eksternal lebih mengarah pada perilaku yang dipengaruhi oleh situasi dimana seseorang tersebut tinggal (Sulistianingtyas et al., 2018).

Teori Atribusi dinilai relevan untuk menjelaskan penelitian ini. Kepatuhan wajib pajak secara sederhana menggambarkan seberapa patuh seorang wajib pajak terhadap peraturan perpajakan yang berlaku (Aktaş et al., 2019) perilaku patuh timbul karena adanya kesediaan wajib pajak untuk membayar pajak, yang didasari oleh penilaian terhadap pajak itu sendiri. Berbagai faktor dapat mempengaruhi kesediaan wajib pajak untuk patuh membayar pajak, baik yang 
berasal dari internal maupun eksternal. Faktor internal yang dimaksud dalam penelitian ini adalah pengetahuan perpajakan yang dimiliki oleh wajib pajak. Variabel sosialisasi perpajakan dan penerapan SAMSAT keliling, diduga adalah faktor eskternal yang memengaruhi kesediaan wajib pajak untuk patuh membayar pajak.

Pengetahuan perpajakan didefinisikan sebagai sensitivitas wajib pajak terhadap peraturan perpajakan, yang mengacu pada sejauh mana kesadaran wajib pajak pada peraturan dan informasi yang terkait dengan perpajakan. Pengetahuan perpajakan berperan penting dalam meningkatkan kepatuhan wajib pajak (Oladipupo \& Obazee, 2016). Wajib pajak dengan pengetahuan perpajakan yang baik memiliki kesadaran yang lebih tinggi akan pentingnya pajak dalam kehidupan bernegara, sehingga kewajiban perpajakan akan dijalankan secara sukarela. Wajib pajak yang tidak memahami perpajakan dengan baik cenderung memiliki kesadaran yang lebih rendah, sehingga wajib pajak cenderung mejalankan kewajiban perpajakan atas dasar keterpaksaan karena adanya undang-undang tanpa memahami esensi yang terkandung di dalamnya. Hal yang lebih serius adalah bahwa pengetahuan perpajakan yang rendah seringkali menjadi penyebab wajib pajak tidak menjalankan kewajiban perpajakannya.

Wijayanti \& Sukartha, (2018) dalam penelitiannya menyatakan bahwa pengetahuan perpajakan memengaruhi patuh tidaknya wajib pajak dalam menjalankan kewajibannya secara positif dan signifikan. Pernyataan tersebut bermakna bahwa wajib pajak akan semakin patuh sejalan dengan semakin tingginya pengetahuan perpajakan yang dimiliki. Temuan serupa juga diungkapkan dalam penelitian, Chusaeri et al., (2017), serta Tresnalyani \& Jati, (2018) bahwa patuh tidaknya wajib pajak dipengaruhi oleh adanya pengetahuan perpajakan. Berdasarkan pembahasan teori dan hasil penelitian sebelumnya dapat dinyatakan bahwa semakin baik pengetahuan perpajakan yang dimiliki oleh wajib pajak, maka semakin tinggi tingkat kepatuhan wajib pajak dalam menjalankan kewajiban perpajakannya.

$\mathrm{H}_{1}$ : Pengetahuan perpajakan berpengaruh positif pada kepatuhan wajib pajak di Kantor Bersama SAMSAT Kabupaten Bangli.

Upaya untuk meningkatkan kepatuhan wajib pajak juga dapat dilakukan dengan memperkuat pendidikan mengenai pajak melalui sosialisasi, baik secara formal maupun informal (Mukhlis et al., 2014). Herawati et al., (2018) dalam penelitiannya menjelaskan bahwa sosialisasi juga menjadi sarana komunikasi yang paling berpengaruh antara pemerintah dengan wajib pajak dalam rangka menyamakan persepsi mengenai perpajakan dan upaya untuk memaksimalkan penerimaannya. Sosialisasi yang optimal membuat wajib pajak memahami pentingnya membayar pajak, kebijakan perpajakan yang berlaku, dan mekanisme pembayaran pajak, sehingga menumbuhkan kesadaran wajib pajak untuk membayar pajak. Sosialisasi perpajakan yang tidak optimal akan mengurangi informasi yang seharusnya diterima wajib pajak. Kondisi ini berdampak pada rendahnya pemahaman mengenai kewajiban perpajakan dan cara melaksanakannya, sehingga memunculkan keinginan untuk tidak menjalankan tugasnya sebagai wajib pajak. 
Novitasari (2015) dalam penelitiannya terhadap wajib pajak Kendaraan Bermotor dan Bea Balik Nama Kendaraan Bermotor menemukan adanya pengaruh sosialisasi perpajakan pada perilaku patuh wajib pajak secara positif dan signifikan. Wajib pajak yang memeroleh sosialisasi perpajakan dengan baik cenderung lebih patuh dalam melaksanakan kewajibannya. Temuan serupa juga diuangkapkan dalam penelitian Dewi \& Jati (2018), Wijayanti \& Sukartha (2018). Berdasarkan pembahasan teori dan hasil penelitian sebelumnya dapat dinyatakan bahwa semakin baik sosialisasi perpajakan yang diperoleh wajib pajak, maka kepatuhan wajib pajak juga akan semakin meningkat.

$\mathrm{H}_{2}$ : Sosialisasi perpajakan berpengaruh positif pada kepatuhan wajib pajak kendaraan bermotor di Kantor Bersama SAMSAT Kabupaten Bangli.

SAMSAT Keliling adalah layanan pengesahan Surat Tanda Nomor Kendaraan (STNK), pembayaran Pajak Kendaraan Bermotor (PKB), dan Sumbangan Wajib Dana Kecelakaan Lalu Lintas Jalan (SWDKLLJ) dengan menggunakan kendaraan bermotor yang beroperasi dari satu tempat ke tempat yang lainnya. SAMSAT Keliling memungkinkan adanya pemerataan dalam pemberian layanan bagi wajib pajak yang tidak bisa datang langsung untuk mengurus kewajiban perpajakan ke Kantor Bersama SAMSAT. Prosedur pelayanan pembayaran Pajak Kendaraan Bermotor yang lebih sederhana, cepat, dan praktis ditambah adanya website untuk mengakses informasi akan memberikan kemudahan bagi wajib pajak.

Ardiani et al., (2016) dalam hasil penelitiannya mengungkapkan bahwa ada kepuasan yang dirasakan wajib pajak dengan adanya layanan inovasi SAMSAT Keliling, karena dianggap lebih memudahkan wajib pajak. Kemudahan dalam memenuhi kewajiban perpajakan akan mendorong wajib pajak untuk lebih patuh dalam menjalankan kewajiban perpajakannya. Pernyataan ini sejalan dengan penelitian Dwipayana et al., (2017) yang menemukan bahwa penerapan layanan SAMSAT Keliling berpengaruh positif pada kepatuhan wajib pajak.

Berdasarkan pembahasan teori dan hasil penelitian sebelumnya dapat dinyatakan bahwa semakin baik penerapan layanan SAMSAT keliling, maka kepatuhan wajib pajak kendaraan bermotor juga akan meningkat.

$\mathrm{H}_{3}$ : Penerapan layanan SAMSAT Keliling berpengaruh positif pada kepatuhan wajib pajak di Kantor Bersama SAMSAT Kabupaten Bangli.

\section{METODE PENELITIAN}

Penelitian dilakukan pada wajib pajak kendaraan bermotor yang terdaftar pada Kantor Bersama SAMSAT Kabupaten Bangli per 31 Desember 2018 yaitu sejumlah 62.556 wajib pajak. Jumlah responden dihitung menggunakan rumus Slovin dan diperoleh sebanyak 100 orang wajib pajak. Penentuan responden dalam penelitian ini menggunakan metode accidental sampling. Responden ditentukan berdasarkan kebetulan, yaitu siapa saja yang secara kebetulan bertemu dengan peneliti dan dipandang sesuai sebagai sumber data. Data penelitian diperoleh melalui penyebaran kuesioner kepada wajib pajak secara langsung. Pernyataan-pernyataan dalam kuesioner diberi nilai atau skor dengan menggunakan skala Likert dengan rentang nilai 1 sampai dengan 4, yaitu Sangat Tidak Setuju (STS), Tidak Setuju (TS), Setuju (S), dan Sangat Setuju (SS). 
Variabel pengetahuan perpajakan berkaitan dengan seberapa jauh wajib pajak memahami hukum, peraturan perundang-undangan, dan metode dalam melaksanakan kewajiban perpajakan dengan benar (Wardani \& Rumiyatun, 2017). Miftahus (2019) dalam penelitiannya menyatakan bahwa pengetahuan perpajakan diukur berdasarkan pengetahuan mengenai ketentuan umum dan tata cara perpajakan, fungsi perpajakan, prosedur pembayaran, dan pengetahuan mengenai sistem perpajakan.

Sosialisasi perpajakan merupakan upaya pemberian informasi dan pemahaman oleh pemerintah kepada wajib pajak tentang segala hal yang berkaitan dengan perpajakan mulai dari kebjikan sampai dengan prosedur perpajakan yang harus ditaati wajib pajak. Sosialisasi menurut Wijayanti \& Sukartha, (2018) diukur berdasarkan tata cara, frekuensi, dan kejelasan sosialisasi. Tata cara digunakan untuk menilai bahwa sosialisai dilaksanakan sesuai peraturan yang berlaku. Frekuensi mengukur seberapa sering sosialisasi diberikan kepada wajib pajak. Kejelasan sosialisasi menggambarkan bahwa sosialisasi dapat menyampaikan informasi secara jelas dan benar.

SAMSAT keliling adalah layanan Pengesahan STNK, Pembayaran Pajak Kendaraan Bermotor dan SWDKLLJ dengan menggunakan kendaraan bermotor yang beroperasi dari satu tempat ke tempat lainnya. Adanya layanan yang disediakan oleh pemerintah dalam memfasilitasi pembayaran pajak, diharapkan dapat dimanfaatkan wajib pajak untuk membayar pajak tepat waktu agar tidak ada sanksi atau denda dikemudian hari (Yunianti et al., 2019). Penerapan layanan SAMSAT Keliling dapat dinilai dari adanya akses pajak berupa tempat pelayanan yang strategis dan mudah di jangkau, fasilitas yang disediakan, adanya complaint center dalam menangani keluhan wajib pajak, serta kemudahan dalam mengakses informasi degan adanya website (Dwipayana et al., 2017).

Data penelitian dianalisis dengan menggunakan analisis regresi linear berganda. Sebagai syarat regresi, dilakukan uji asumsi klasik berupa uji normalitas, uji multikolinearitas, dan uji heteroskedastisitas untuk melihat kesesuaian data penelitian. Dari hasil analisis regresi linear berganda dapat diketahui mengenai Uji F (kelayakan model), koefisien determinasi, dan uji t (uji hipotesis). Uji kelayakan model (uji F) bertujuan untuk menguji kelayakan model regresi dalam menganalisis hubungan antara variabel independen dengan. Nilai koefisien determinasi $\left(R^{2}\right)$ menunjukkan seberapa besar kemampuan variabel independen dalam menerangkan variabel dependen. Uji $t$ (uji hipotesis) digunakan untuk menguji signifikansi variabel independen terhadap variabel dependen.

\section{HASIL DAN PEMBAHASAN}

Analisis data menggunakan model regresi linear berganda. Sebelum dilakukan analisis, data penelitian terlebih dahulu harus lolos uji asumsi klasik agar terbebas dari masalah normalitas, multikolonearitas, dan heteroskedastisitas. Setelah dapat dipastikan memenuhi syarat regresi, maka dilakukan analisis regresi linear berganda dengan hasil yang tersaji dalam Tabel 1. 
Tabel 1. Hasil Regresi Linier Berganda

\begin{tabular}{lcccccc}
\hline \multirow{1}{*}{ Variabel } & \multicolumn{2}{c}{$\begin{array}{c}\text { Unstandardized } \\
\text { Coefficients }\end{array}$} & $\begin{array}{c}\text { Standardized } \\
\text { Coefficients }\end{array}$ & $\mathrm{t}$ & \multirow{2}{*}{ Sig. } \\
\cline { 2 - 5 } & $\mathrm{B}$ & Std. Error & Beta & & \\
\hline Pengetahuan perpajakan $\left(\mathrm{X}_{1}\right)$ & 0,421 & 0,116 & 0,349 & 3.634 & 0,000 \\
Sosialisasi Perpajakan $\left(\mathrm{X}_{2}\right)$ & 0,188 & 0,08 & 0,221 & 2.355 & 0,021 \\
Layanan SAMSAT Keliling & 0,192 & 0,083 & 0,229 & 2.308 & 0,023 \\
$\left(X_{3}\right) \quad$ Adjusted R Square & & & 0,428 & & \\
$\quad$ F hitung & & & 25,662 & & \\
$\quad$ Sig. F & & & 0,000 & & \\
\hline
\end{tabular}

Sumber : Data Penelitian, 2020

Analisis regresi linear berganda, mengindikasikan model penelitian yang diformulasikan tergolong layak dengan F-value sebesar 25,662 dan tingkat signifikansi 0,000 atau lebih kecil dari a $=0,05$. Nilai koefisien determinasi $\left(R^{2}\right)$ mengindikasikan bahwa variansi kepatuhan wajib pajak kendaraan bermotor di Kantor Bersama SAMSAT Kabupaten Bangli dipengaruhi secara signifikan oleh variabel pengetahuan perpajakan, sosialisasi perpajakan, dan penerapan layanan SAMSAT Keliling sebesar 42,8 persen, sedangkan sisanya sebesar 57,2 persen dipengaruhi oleh faktor-faktor lain yang tidak dijelaskan dalam model penelitian.

Pengujian terhadap variabel pengetahuan perpajakan menunjukkan tingkat signifikansi 0,000 atau kurang dari 0,05 sehingga $\mathrm{H}_{0}$ ditolak dan $\mathrm{H}_{1}$ diterima. Koefisien regresi menunjukkan nilai positif, yaitu 0,421. Hasil menunjukkan pengetahuan perpajakan memengaruhi secara positif kepatuhan wajib pajak kendaraan bermotor di Kantor Bersama SAMSAT Kabupaten Bangli. Semakin tinggi pengetahuan perpajakan yang dimiliki, maka semakin meningkat pula kepatuhan wajib pajak dalam membayar Pajak Kendaraan Bermotor.

Temuan ini mendukung teori Atribusi dalam menjelaskan mengenai adanya faktor-faktor yang mempengaruhi perilaku seseorang baik secara internal maupun ekstrernal. Pengetahuan perpajakan dapat dikatakan sebagai faktor yang berasal dari dalam diri wajib pajak (internal) yang mempengaruhi perilaku patuh dari seorang wajib pajak untuk membayar Pajak Kendaraan Bermotor. Pengetahuan perpajakan menggambarkan seberapa jauh wajib pajak memahami kewajiban dan hak wajib pajak, pentingnya membayar pajak, dan tata cara pembayaran pajak. Wajib pajak dengan pengetahuan perpajakan yang tinggi dapat menyadari dan melaksanakan kewajiban perpajakannya dengan benar, sehingga wajib pajak cenderung lebih patuh. Temuan ini sejalan dengan penelitian yang dilakukan oleh Wijayanti \& Sukartha (2018), Tresnalyani \& Jati (2018), serta Chusaeri et al., (2017).

Tingkat signifikansi yang lebih rendah dari 0,05 juga terlihat pada hasil pengujian variabel sosialisasi perpajakan, yaitu sebesar 0,021. Koefisien regresi bernilai positif sebesar 0,188 . Hasil pengujian mengindikasikan bahwa $\mathrm{H}_{0}$ ditolak dan $\mathrm{H}_{2}$ diterima, sehingga dapat dinyatakan sosialisasi perpajakan berpengaruh positif terhadap kepatuhan wajib pajak kendaraan bermotor di Kantor Bersama 
SAMSAT Kabupaten Bangli. Hal ini bermakna bahwa sosialisasi yang semakin baik dapat menjadikan kepatuhan wajib pajak semakin meningkat.

Temuan ini mendukung teori Atribusi dalam menjelaskan mengenai adanya faktor-faktor yang mempengaruhi perilaku seseorang untuk patuh terhadap kewajiban perpajakannya baik secara internal maupun ekstrernal. Faktor eksternal tersebut salah satunya berasal dari adanya sosialisasi perpajakan. Pemberian sosialisasi oleh pemerintah membantu masyarakat dalam memeroleh informasi dan pemahaman mengenai perpajakan, yang pada akhirnya akan digunakan sebagai dasar untuk bertindak dan mengambil keputusan sehubungan dengan hak dan kewajibannya sebagai wajib pajak. Hasil penelitian konsisten dengan penelitian terdahulu yang dilakukan oleh Novitasari (2015), Dewi (2018), serta Wijayanti \& Sukartha (2018).

Tingkat signifikansi 0,023 atau kurang dari 0,05 pada pengujian variabel penerapan layanan SAMSAT keliling mengindikasikan hipotesis ketiga $\left(\mathrm{H}_{3}\right)$ dalam penelitian ini diterima. Koefisien regresi menunjukkan nilai positif sebesar 0,192. Layanan SAMSAT Keliling dapat dinyatakan memengaruhi secara positif kepatuhan wajib pajak. Penerapan layanan SAMSAT keliling yang semakin baik akan menjadikan kepatuhan wajib pajak semakin meningkat.

SAMSAT Keliling memungkinkan adanya pemerataan dalam pemberian layanan bagi wajib pajak yang tidak bisa datang langsung untuk mengurus kewajiban perpajakan ke Kantor Bersama SAMSAT. Prosedur pelayanan pembayaran Pajak Kendaraan Bermotor yang lebih sederhana, cepat, dan praktis ditambah adanya website untuk mengakses informasi akan memberikan kemudahan bagi wajib pajak. Kemudahan dalam memenuhi kewajiban perpajakan akan mendorong wajib pajak untuk lebih taat dan patuh terhadap ketentuan perpajakan yang berlaku.

Hasil penelitian menundukung teori Atribusi dalam menjelaskan mengenai adanya faktor-faktor yang mempengaruhi perilaku seseorang baik secara internal maupun ekstrernal. Selain sosialisasi perpajakan, penerapan layanan SAMSAT keliling juga dapat dikatakan sebagai faktor eksternal yang mampu mempengaruhi kepatuhan wajib pajak untuk membayar Pajak Kendaraan Bermotor. Hasil penelitian sejalan dengan penelitian terdahulu yang dilakukan oleh (Dwipayana et al., 2017).

\section{SIMPULAN}

Hasil penelitian menemukan bahwa; 1) pengetahuan perpajakan berpengaruh positif pada kepatuhan wajib pajak kendaraan bermotor. Semakin tinggi pengetahuan perpajakan yang dimiliki oleh wajib pajak, maka kepatuhan wajib pajak dalam membayar Pajak Kendaraan Bermotor juga semakin meningkat. 2) Sosialisasi perpajakan berpengaruh positif pada kepatuhan wajib pajak kendaraan bermotor di Kabupaten Bangli. Hal ini menunjukkan bahwa semakin baik sosialisasi perpajakan, maka kepatuhan wajib pajak dalam membayar Pajak Kendaraan Bermotor juga semakin meningkat. 3) Penerapan layanan SAMSAT keliling berpengaruh positif pada kepatuhan wajib pajak kendaraan bermotor di Kantor Bersama SAMSAT Kabupaten Bangli. Temuan ini bermakna bahwa semakin baik penerapan layanan SAMSAT keliling, maka kepatuhan wajib pajak dalam membayar Pajak Kendaraan Bermotor juga semakin meningkat. 


\section{REFERENSI}

Aktaş Güzel, S., Özer, G., \& Özcan, M. (2019). The effect of the variables of tax justice perception and trust in government on tax compliance: The case of Turkey. Journal of Behavioral and Experimental Economics , 78(January 2018), 80-86. https:// doi.org/10.1016/j.socec.2018.12.006

Andreas, \& Savitri, E. (2015). The Effect of Tax Socialization, Tax Knowledge, Expediency of Tax ID Number and Service Quality on Taxpayers Compliance with Taxpayers Awareness as Mediating Variables. Procedia Social and Behavioral Sciences, 211 (September), 163-169. https:// doi.org/10.1016/j.sbspro.2015.11.024

Ardiani, L., Hidayat, K., \& Sulasmiyati, S. (2016). Implementasi Layanan Inovasi Samsat Keliling Dalam Upaya Meningkatkan Pelayanan Pembayaran Pajak Kendaraan Bermotor (Studi Pada Kantor Bersama SAMSAT Kabupaten Tulungagung). Jurnal Perpajakan (JEJAK), 9(1), 1-8.

Awaluddin, I., \& Tamburaka, S. (2017). The Effect of Service Quality and Taxpayer Satisfaction on Compliance Payment Tax Motor Vehicles at Office One Roof System in Kendari. The International Journal of Engineering and Science (IJES), 6(11), 25-34. https:// doi.org/10.9790/1813-0611012534

Chusaeri, Y., Daiana, N., \& Afifudin. (2017). Pengaruh Pemahaman Dan Pengetahuan Wajib Pajak Tentang Peraturan Perpajakan, Kesadaran Wajib Pajak, Kualitas Pelayanan, Dan Sanksi Perpajakan Terhadap Kepatuhan Wajib Pajak Kendaraan Bermotor (Studi Samsat Kota Batu). Jurnal Ilmiah Riset Akuntansi, 6(9), 1-29.

Danarsi, Nurlaela, S., \& Subroto, H. (2017). Faktor-faktor yang Mempengaruhi Kepatuhan Wajib Pajak dalam Membayar Pajak Mobil dengan Diberlakukannya Pajak Progresif di Kota Surakarta. Jurnal Akuntansi Dan Pajak, 18(01), 45-55.

Dewi, N. K. A. P., \& Jati, I. K. (2018). Pengaruh Sosialisasi, Kualitas Pelayanan, Sanksi dan Biaya Kepatuhan Pada Tingkat Kepatuhan Wajib Pajak Kendaraan Bermotor. 25(1), 1-30. https://doi.org/DOI: https:// doi.org/10.24843/EJA.2018.v25.i01.p01

Dwipayana, I. M. H., Dewi, P. E. D. M., \& Yasa, I. I. N. P. (2017). Pengaruh Program Samsat Corner, Samsat Keliling Dan Kepuasan Wajib Pajak Terhadap Kepatuhan Wajib Pajak Dalam Membayar Pajak Kendaraan Bermotor (PKB) (Studi Empiris Pada Kantor Bersama Sistem Administrasi Manunggal di Bawah Satu Atap (SAMSAT) Denpasar). E-Jurnal S1 Ak, 8(2).

Gustiari, L. A., \& Suprasto, H. B. S. (2018). Sosialisasi Perpajakan Memoderasi Pengaruh Kewajiban Moral dan Kualitas Pelayanan pada Kepatuhan Wajib Pajak Kendaraan Bermotor Fakultas Ekonomi dan Bisnis Universitas Udayana ( Unud ), Bali , Indonesia Fakultas Ekonomi dan Bisnis Universitas Udayana ( Un. E-Jurnal Akuntansi Universitas Udayana, 24(1), 606-632. https:// doi.org/https:/ / doi.org/10.24843/EJA.2018.v24.i01.p23

Herawati, H., Tabroni, R., \& Lusiana, S. (2018). The Effectiveness of The Tax Regulation Socialization Strategies o n Tax Payers ' Comprehension and Compliance In Implementing Their Tax Obligations. The International Journal Of Business Review (The Jobs Review), 1(2), 145-153. 
Ilhamsyah, R., Endang, M. G. W., \& Dewantara, R. Y. (2016). Pengaruh Pemahaman Dan Pengetahuan Wajib Pajak Tentang Peraturan Perpajakan, Kesadaran Wajib Pajak, Kualitas Pelayanan, Dan Sanksi Perpajakan Terhadap Kepatuhan Wajib Pajak Kendaraan Bermotor (Studi Samsat Kota Malang). Jurnal Perpajakan (JEJAK), $8(1)$. https:// doi.org/10.1017/CBO9781107415324.004

Lianty, R. A. M., Hapsari, D. W., \& Kurnia. (2017). Pengetahuan perpajakan, sosialisasi perpajakan, dan pelayanan fiskus terhadap kepatuhan wajib pajak. Jurnal Riset Akuntansi Kontemporer (JRAK), 9(2), 55-65.

Mahaputri, N. N. T., \& Noviari, N. (2016). Pengaruh Pemahaman Peraturan Perpajakan, Kesadaran Wajib Pajak Dan Akuntabilitas Pelayanan Publik Terhadap Kepatuhan Wajib Pajak. 17(3), 2321-2351.

Mukhlis, I., Utomo, S. H., \& Soesetio, Y. (2015). The Role of Taxation Education on Taxation Knowledge and Its Effect on Tax Fairness as well as Tax Compliance on Handicraft SMEs Sectors in Indonesia. International Journal of Financial Research, 6(4). https://doi.org/10.5430/ijfr.v6n4p161

Mukhlis, I., Utomo, S. H., \& Soesetyo, Y. (2014). Increasing Tax Compliance Through Strengthening Capacity Of Education Sector For Export Oriented SMES Handicraft Field In East Java Indonesia. European Scientific Journal, 10(7).

Nahumury, J., Wayan Wisnu Utama, I., \& Hari Suryaningrum, D. (2018). the Compliance of Motor Vehicle Taxpayers: an Experimental Research. Journal of Accounting and Strategic Finance, 1(1), 163-176. https:// doi.org/10.33005/jasf.v1i2.44

Novitasari, R. (2015). Pengaruh Kesadaran Wajib Pajak, Sosialisasi Perpajakan, Kualitas Pelayanan Pada Kepatuhan Wajib Pajak Di Samsat Semarang III. 3.

Nurhayati, N., Halimatusadiah, E., \& Diamonalisa. (2015). Influence of tax officer service quality and knowledge of tax on individual taxpayer compliance in tax office (kpp) Bojonagara Bandung. International Journal of Applied Research, 1(8), 805-809.

Nurlis, \& Kamil, I. (2015). The Effect of Taxpayer Awareness , Knowledge , Tax Penalties and Tax Authorities Services on the Tax Complience: (Survey on the Individual Taxpayer at Jabodetabek \& Bandung ). Research Journal of Finance and AccountingOnline), 6(2), 104-112.

Oladipupo, A. O., \& Obazee, U. (2016). Tax Knowledge, Penalties and Tax Compliance in Small and Medium Scale Enterprises in Nigeria. IBusiness, 08(01), 1-9. https://doi.org/10.4236/ib.2016.81001

Rahmawati, R., \& Yulianto, A. (2018). Analysis of the Factors Affecting Individual Taxpayers Compliance. Accounting Analysis Journal, 7(1), 17-24. https:// doi.org/10.15294/aaj.v5i3.18411

Savitri, E., \& Musfialdy. (2016). The Effect of Taxpayer Awareness, Tax Socialization, Tax Penalties, Compliance Cost at Taxpayer Compliance with Service Quality as Mediating Variable. Procedia - Social and Behavioral Sciences, 219, 682-687. https://doi.org/10.1016/j.sbspro.2016.05.051

Sukmawati, F. (2011). The Effects of Understanding Taxpayers ' Understanding Tax Penalty on Taxpayers ' Compliance in KPP Karees Bandung. 26-31.

Sulistianingtyas, V., Rosidi, \& Subekti, I. (2018). A Perspective of Theory of Planned 
Behavior and Attribution Theory for PBB P2 Taxpayer Compliance in Probolinggo. 2(2), 320-347.

Tresnalyani, N. K. M., \& Jati, I. K. (2018). Pengaruh Kualitas Pelayanan, Pengetahuan Perpajakkan dan Biaya Kepatuhan pada Kepatuhan Wajib Pajak Kendaraan Bermotor. E-Jurnal Akuntansi Universitas Udayana, 24(1), 578. https:// doi.org/10.24843/eja.2018.v24.i01.p22

Ummah, M. (2015). Pengaruh Kesadaran Wajib Pajak, Sanksi Pajak, Pengetahuan Perpajakan Dan Pelayanan Fiskus Terhadap Kepatuhan Wajib Pajak Kendaraan Bermotor Di Kabupaten Semarang. Jurnal Ekonomi, 1-14. https:// doi.org/10.1007/s13398-014-0173-7.2

Wardani, D. K., \& Rumiyatun. (2017). Pengaruh Pengetahuan Wajib Pajak, Kesadaran Wajib Pajak, Sanksi Pajak Kendaraan Bermotor Dan Sistem Samsat Drive Thru Terhadap Kepatuhan Wajib Pajak Kendaraan Bermotor. Jurnal Ilmiah Akuntansi Universitas Pamulang, 7(1), 76. https:// doi.org/10.32493/jiaup.v7i1.2508

Wijayanti, L. P. C., \& Sukartha, I. M. (2018). Pengaruh Tarif Progresif , Kualitas Pelayanan, Sosialisasi Perpajakan dan Pengetahuan Perpajakan Pada Kepatuhan Wajib Pajak. E-Jurnal Akuntansi Universitas Udayana, 25(3), 20112040. $\quad$ https://doi.org/https://doi.org/10.24843/EJA.2018.v25.i03.p15 Pengaruh

Yunianti, L. N., Putri, N. K., Sudibyo, Y. A., \& Rafinda, A. (2019). The Influence of Awareness, Moral Obligations, Tax Access, Service Quality and Tax Sanctions on Taxpayer Compliance in Paying Motor Vehicle Tax. Journal of Accounting and Strategic Finance, 2(1), 1-13. https:// doi.org/10.33005/jasf.v2i1.20 